УДК 347.43(477)

DOI https://doi.org/10.32849/2663-5313/2019.5.09

\title{
Вікторія Рассказова,
}

старший викладач кафедри иивільного права та процесу

Харківського начіонального університету внутрішніх справ

\section{ЮРИДИЧНІ ОСОБЛИВОСТІ ВІДНОСИН ІЗ ВІДСТУПНОГО}

Стаття присвячена аналізу юридичних особливостей правовідносин із відступного, визначенню правової природи й ознак відступного як самостійної, порівняно нової підстави припинення зобов'язання в иивільному праві України з метою вдосконалення практики застосування наиіонального законодавства в зазначеній галузі та єдиного розуміння природи відступного й відповідних правовідносин.

Ключові слова: відступне, правовідносини, припинення зобов'язання, заміна предмета зобов’язання, угода про відступне, юридичні особливості.

Постановка проблеми. Незважаючи на те що інститут відступного є порівняно новою конструкцією в теорії та практиці вітчизняного цивільного права, використання вказаного механізму припинення зобов'язання набуває все більшого поширення, адже відступне $є$ гнучким інструментом ефективного врегулювання цивільно-правових відносин, захисту прав і законних інтересів боржника і кредитора в такий спосіб, що дає змогу припинити цивільне зобов'язання незалежно від наявності чи відсутності факту неналежного виконання чи невиконання зобов'язання боржником, запобігаючи можливим майновим і немайновим утратам та орієнтуючись на інтереси учасників. Утім, будучи дієвим інструментом регулювання цивільно-правових відносин в умовах реального існування свободи договору, практика застосування цього правового інституту виявила спірні питання, пов'язані з використанням відступного в цивільному обороті, що, у свою чергу, потребує окремого вивчення.

Хоча чимало наукових досліджень присвячені системі підстав припинення цивільного зобов'язання, їх юридичним особливостям і порівняльній характеристиці в тому числі з відступним, водночас саме цей інститут зобов'язального права не був предметом окремого вивчення у вітчизняній науці цивільного права. Деякі аспекти правової характеристики відступного висвітлено в працях А.М. Блащука, Т.В. Боднар, Л.К. Жданкіної, А.В. Коструби, О.Я. Кузьмича, О.І. Міхно, С.В. Падуна, І.Й. Пучковської, Ф.А. Шимка, О.С. Яворської та інших.

Тож питання правової природи відступного як самостійної підстави припинення цивільного зобов'язання, виявлення характерних ознак, проблем практичного застосування цього правового інституту, юридичних особливостей відносин із відступного можна зарахувати до питань, що в теоретичному аспекті недостатньо висвітлені в сучасній цивілістичній літературі й залишаються актуальними для подальших наукових розвідок.

Дослідження юридичних особливостей правовідносин щодо застосування сторонами відступного грунтується насамперед на дослідженні цього інституту як автономної підстави в системі підстав припинення зобов'язальних правовідносин, що зумовлює наявність у правовій характеристиці відступного власних, притаманних лише цьому інституту юридичних особливостей.

Мета статті - проаналізувати юридичні особливості правовідносин із відступного, визначити правову природу й ознаки відступного як самостійної, порівняно нової підстави припинення зобов'язання в цивільному праві України з метою вдосконалення практики застосування національного законодавства в зазначеній галузі та єдиного розуміння природи відступного й відповідних правовідносин.

Виклад основного матеріалу. Передання відступного як самостійна підстава запроваджена в цивільне законодавство лише 3 прийняттям Цивільного кодексу України 2003 року (далі - ЦК України) [1], який передбачає, що зобов'язання припиняється за згодою сторін унаслідок передання боржником кредиторові відступного (грошей, іншого майна тощо). Розмір, строки й порядок передання відступного встановлюються сторонами (ст. 600 ЦК України). Як бачимо, вказані нормативні положення надають стислу законодавчу характеристику інституту відступного як одного із самостійних способів припинення цивільного зобов'язання 
виключно за волею сторін і передбачають заміну первісного предмета виконання іншим, що має на меті припинення первісного зобов'язання.

Хоча в науковій дискусії висловлюються думки, що відступне $\epsilon$ видом чи складником іншої підстави припинення цивільного зобов'язання - за домовленістю (ст. 604 ЦК України), вважаємо, що передання відступного є самостійним способом ліквідації правових зв'язків між учасниками зобов'язальних правовідносин, на користь чого свідчить не лише формулювання конструкції відступного в окремій ст. 600 ЦК України, а й низка юридичних особливостей і відмінних ознак цієї підстави. При цьому необхідність досягнення згоди, на нашу думку, є критерієм класифікації підстав припинення зобов'язання та водночас ознакою відповідної групи підстав, які передбачають припинення зобов'язання за волею сторін (новація, прощення боргу, зарахування).

Заслуговує на увагу думка О.Ю. Шилохвоста, котрий також указує, що відступне є самостійним інститутом, зміст якого не може бути зведено до жодного іншого. Разом із тим, як зауважує вчений, володіючи рисами деяких інших інститутів, відступне виступає як комплексний інститут, що опосередковує не тільки завдання припинення зобов'язань, а й за певних умов завдання забезпечення виконання зобов'язання [2].

Законодавче формулювання «за згодою сторін» означає імперативну вимогу про необхідність досягнення між сторонами домовленості про припинення зобов'язання саме в спосіб передання відступного. Обов'язковість досягнення згоди щодо припинення зобов'язань відступним тягне за собою необхідність відповідної фіксації такої згоди. Тож визначальною особливістю відступного, як і відповідних правовідносин, є специфіка правової природи договору про відступне.

Оскільки законодавець не обмежує сторони в можливості досягнення згоди на передання відступного в будь-який момент розвитку зобов'язальних правовідносин, можна дійти висновку, що узгодити умови передання відступного сторони можуть як заздалегідь, передбачивши відповідні застереження в правочині щодо первісного зобов'язання, так i в процесі виконання зобов'язання, уклавши двосторонній правочин (договір) про відступне, який має відповідати вимогам до форми та змісту, необхідним для основного зобов'язання, враховуючи встановлені законодавством вимоги до предмета відступного.

Істотними умовами угоди про відступне, згідно із законодавчою вказівкою, є розмір, строки й порядок передання відступного.
Водночас законодавець не обмежує сторін у виборі предмета відступного, закріплюючи невичерпний перелік майнових цінностей як відступне (рухомі, нерухомі речі, майнові комплекси підприємств, майнові права, навіть виконання робіт, надання послуг); не обмежує розмір відступного, який може й не відповідати вартості предмета первісного зобов'язання, проте задовольняти обидві сторони. При цьому застосування відступного допускається для припинення будь-яких зобов'язань і на будь-якій стадії розвитку зобов'язальних правовідносин.

Як бачимо, сторони вільні у праві визначати низку елементів юридичного складу відступного, орієнтуючись на власні інтереси та домовляючись про вигідні для кожного з них юридичні наслідки, що вказує на універсальність цієї підстави припинення цивільного зобов'язання й широку дискрецію сторін під час застосування цього інституту 3 метою врегулювання зобов’язальних відносин.

Аналіз ст. 600 ЦК України дає змогу стверджувати, що законодавець визначив домовленість про передання відступного як двосторонній, консенсуальний, оплатний правочин, метою якого передусім $є$ припинення первісного зобов'язання. На користь консенсуальної природи договору про відступне свідчить указівка законодавця на визначення строків передання предмета відступного, тобто наявність певного часового проміжку між досягненням згоди сторін щодо припинення первісного зобов'язання у визначений спосіб і фактом передання відступного.

Будучи прибічником консенсуальної природи угоди про відступне, О.Ю. Шилохвост у працях указує, що саме така модель домовленості про відступне дає змогу охопити всю різноманітність об'єктів зобов'язальних правовідносин [2, с. 11].

Варто звернути увагу на те, що моментом припинення основного зобов'язання є саме факт передання боржником і прийняття кредитором предмета відступного на виконання домовленості між сторонами про передання відступного, тобто згода сторін про передання відступного автоматично не припиняе первісне зобов'язання, що узгоджується 3 тим, що законодавець прямо пов'язує настання правових наслідків у вигляді припинення зобов'язання з фактом надання відступного, зокрема про це свідчить законодавча вказівка на те, що первісне зобов'язання припиняється за згодою сторін «внаслідок передання боржником кредиторові відступного».

Тобто правовий зв'язок сторін угоди про відступне продовжує існувати до моменту фактичного передання предмета відступного. 
При цьому варто звернути увагу на те, що на законодавчому рівні єдиним наслідком передання кредиторові узгодженого сторонами відступного визначено припинення первісного зобов'язання, про що свідчить імперативна вказівка законодавця «припиняється».

Тож важливою ознакою відступного $є$ мета, якою сторони керуються під час застосування цієї конструкції, і власне функція цього правового інституту - припинення зобов'язальних відносин між сторонами, а не збереження таких відносин у трансформованому вигляді, як це має місце під час новації. При цьому особливим є спосіб припинення первісного зобов'язання - надання відступного (зміненого предмета виконання), чим фактично виконується зобов'язання.

Із цього приводу варто частково не погодитися з думкою Є.В. Падуна, який указує, що «під час відступного волевиявлення контрагентів спрямовано на збереження первісного зобов'язання з наданням боржнику права відкупитися від його виконання (замінити первісний предмет виконання) і тим самим припинити дію основного зобов'язання» [3, с. 95]. Уважаємо, що воля сторін при відступному спрямована саме на припинення наявного зобов'язання, до якого 3 тих чи інших причин утрачено інтерес, що досягається шляхом надання обумовленого предмета відступного. Іншими словами, надання боржнику права відкупитися від виконання зобов'язання (замінити первісний предмет виконання) є обраним сторонами способом припинення зобов'язання, якому надано перевагу як найбільш вигідному порядку ліквідації правових зв'язків.

Досліджуючи конструкцію відступного за білоруським законодавством, Я. Функ зауважує, що «базова правова відмінність між новацією й відступним як способами припинення цивільно-правових зобов'язань полягає в тому, що при новації правовий зв'язок між суб'єктами-учасниками первісного зобов'язання зберігається (вона триває в рамках нового зобов'язання), а при відступному припиняється не тільки первісне зобов'язання, а й усі відносини між відповідними суб'єктами» [4].

Відповідно до ст. 380 Цивільного кодексу Республіки Білорусь, указане за угодою сторін зобов'язання може бути припинено наданням замість виконання відступного (сплатою грошей, передачею майна тощо). Розмір, строки й порядок надання відступного встановлюються сторонами [5]. Як бачимо, зауваження Я. Функа є слушним і для подібної конструкції відступного в українському цивільному законодавстві, адже передання відступного має наслідком при- пинення правових зв'язків між сторонами без установлення нових зобов'язань. Варто вказати, що подібний підхід до визначення природи відступного закріплений також у Цивільному кодексі Азербайджанської Республіки (ч. 8 ст. 529) [6].

Крім того, варто звернути увагу на співвідношення первісного зобов'язання, щодо якого була домовленість про припинення переданням відступного, і зобов'язання, основаного на угоді про передання відступного, що спрямовано на припинення первісного. У наукових колах висловлюються думки про одночасне існування двох взаємовиключних зобов'язань і права кредитора вимагати на власний вибір від боржника або виконання первісного зобов'язання, або надання відступного.

Так, Ю.Л. Сенін указує, що укладання консенсуального договору про відступне передбачає існування альтернативного обов'язку: передати або предмет основного зобов'язання, або предмет відступного, тоді як новація передбачає припинення первісного обов'язку та виникнення нового без альтернативності $[7$, с. 6].

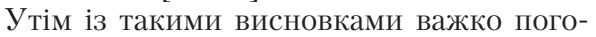
дитися, адже, виходячи 3 консенсуальної природи договору про передання відступного й мети такої домовленості, варто приєднатися до думки, що правова природа договору про відступне наділяє кожну зі сторін такого правочину «комплектом» прав та обов'язків одна стосовно одної: 3 досягненням відповідної угоди про відступне первісний кредитор має право вимагати передання предмета відступного й водночас позбавлений права вимагати від боржника виконання первісного обов'язку, а боржник зобов'язаний виконати обов'язок, визначений договором про відступне, і позбавляється первісного обов'язку [8, с. 159].

Уважаємо, що в разі характеристики відступного через призму існування альтернативного обов'язку передати або предмет основного зобов'язання, або предмет відступного, нівелюється сутність відступного як механізму припинення зобов'язання за волею сторін на засадах рівності й свободи договору, адже в такій ситуації боржник опиняється в більш уразливому становищі та позбавляється зацікавленості в переданні відступного, оскільки в будь-який момент кредитор може вимагати виконання первісного зобов'язання замість передання узгодженого сторонами предмета відступного.

Саме таке розуміння правової природи відступного відображає законодавчу конструкцію цього інституту зобов'язального права. 
Тож юридичною особливістю відносин із відступного є наявність фактичного складу домовленість про передання відступного як двосторонній, консенсуальний, оплатний правочин і власне надання предмета відступного як правоприпиняючий юридичний факт. Інакше, якщо розуміти, що первісне зобов'язання припиняється лише фактом укладення угоди про передання відступного, відбувається ототожнення відступного та новації, що суперечить чинному законодавству.

Із цього приводу варто звернути увагу на висновки Верховного Суду щодо умов та ознак новації, які вказують на ключові відмінності цієї підстави припинення зобов'язання від відступного, зокрема колегія суддів Першої судової палати Касаційного цивільного суду в Постанові від 13 березня 2019 року у справі № 609/67/18 указала, що «новація - це угода про заміну первинного зобов'язання новим зобов'язанням між тими самими сторонами. Вона не припиняє правового зв'язку сторін, оскільки, замість зобов'язання, дія якого припиняється, виникає узгоджене ними нове зобов'язання». При цьому ознаками новації, на які суд звертає увагу, є спосіб припинення зобов'язання; вона можлива лише між тими самими сторонами (сторонами попереднього зобов'язання); є двостороннім правочином (договором); нове зобов'язання пов'язане 3 попереднім і спрямоване саме на заміну первісного зобов'язання новим, а не на зміну цього зобов'язання [9].

Отже, юридичними особливостями відносин із відступного варто вказати такі: 1) юридичною підставою для передання відступного є домовленість сторін про припинення первісного зобов'язання шляхом заміни предмета виконання; 2) метою відступного $€$ припинення первісного зобов'язання; 3) угода про відступне має договірну природу: є консенсуальним, двостороннім та оплатним договором, який має правоприпиняючу дію; 4) моментом припинення первісного зобов'язання є передання відступного, тобто його виконання; 5) універсальність і гнучкість інструментів регулювання, що передбачає можливість сторін на власний розсуд вирішувати питання щодо предмета, строків, порядку надання відступного, відсутність обмежень щодо видів зобов'язань, строків застосування відступного, поведінки сторін тощо.

Визначення відступного як підстави припинення цивільного зобов'язання, яке б відображало вказані особливості відповідних правовідносин, варто визначити як основане на згоді сторін припинення правових зв'язків між сторонами шляхом передання боржни- ком іншого предмета виконання первісного зобов'язання.

\section{Висновки}

Правовідносини щодо надання відступного характеризуються низкою юридичних особливостей, які відображають відмінності відступного від інших підстав припинення зобов'язання, притаманні лише цьому правовому інституту риси й умови реалізації. Застосування відступного як універсального способу припинення зобов'язання, що передбачає досягнення сторонами домовленості щодо передання визначеного предмета відступного, зафіксованої у відповідному договорі, дає змогу припинити небажані правові зв'язки між контрагентами, позбавитися тих зобов'язань, до яких утрачено інтерес, і захистити права сторін у той час існування зобов'язальних правовідносин, коли це вимагається, і в тих випадках, коли інші підстави припинення зобов’язання не можуть бути застосовані.

Визначення відступного як основаного на згоді сторін припинення правових зв'язків між сторонами шляхом передання боржником іншого предмета виконання первісного зобов'язання дає змогу відобразити особливості цієї правової конструкції, іiї відмінність від подібних інститутів зобов'язального права та ускладненість і специфіку правовідносин між сторонами, які бажають припинити зобов'язання переданням відступного.

Уважаємо, що подальшого дослідження як на теоретичному рівні, так і в розрізі практики застосування цього інституту потребують інші питання врегулювання правовідносин щодо передання відступного, зокрема підстави та юридичні наслідки визнання угоди про відступне недійсною, відповідальності за невиконання чи неналежне виконання умов щодо передання відступного тощо.

\section{Список використаних джерел:}

1. Цивільний кодекс України: Закон України від 16.01.2016 № 435-IV. Дата оновлення: 04.11.2018. URL: http://zakon.rada.gov.ua/laws/ show/435-15 (дата звернення: 11.04.2019).

2. Шилохвост О.Ю. Отступное как способ прекращения обязательств в гражданском праве России: автореф. дисс. ... канд. юрид. наук: спец. 12.00.03. Москва, 1999. 26 с.

3. Падун Є.В. Критерії відмежування відступного від новації в цивільному праві України. Науковий вісник Національної академії внутрішніх справ. 2013. № 3. C. 91-97. URL: http:// nbuv.gov.ua/UJRN/Nvknuvs_2013_3_13 (дата звернення: 11.04.2019).

4. Функ Я. О природе отступного и его отличии от новации при использовании в хозяйственной деятельности. Я - юрисконсульт организации. 
2017. № 1. C. 10-12. URL: https://www.jurk.by/ izdaniya/ya-spok/o-prirode-otstupnogo-i-egootlichii-ot-n 0000000 (дата звернення: 11.04.2019).

5. Гражданский кодекс Республики Беларусь: Закон от 07.12.1998 № 218-3. Дата оновлення: 17.07.2018. URL: http://base.spinform.ru/show doc.fwx?rgn=1822 (дата звернення: 11.04.2019).

6. Гражданский кодекс Азербайджанской Республики: Закон от 28.12.1999. Дата оновлення: 28.12.2018. URL: https://online.zakon.kz/document/? doc_id=30420111 (дата звернення: 11.04.2019).
7. Сенін Ю.Л. Новація як спосіб припинення зобов'язань за цивільним законодавством України: автореф. дис. ... канд. юрид. наук: спец. 12.00.03. Одеса, 2013. 20 c

8. Шимко Ф.А. Співвідношення прощення боргу та інших суміжних інститутів цивільного права. Науковий вісник Херсонського державного університету. 2015. Вип. 5. Т. 1. С. 157-160.

9. Постанова Касаційного цивільного суду у складі Верховного Суду від 13 березня 2019 року у справі № 609/67/18.

Статья посвящена анализу юридических особенностей правоотношений, что возникают на основании отступного, определению правовой природы и признаков отступного как самостоятельного, сравнительного нового основания прекращения обязательства в гражданском праве Украины с иелью совершенствования практики применения национального законодательства в указанной области и общего понимания природы отступного и соответствующих правоотношений.

Ключевые слова: отступное, правоотношения, прекращение обязательства, замена предмета обязательства, соглашение об отступном, юридические особенности.

In the article are considered the legal peculiarities of legal relations that arise on the basis of retreat, the definition of the legal nature and signs of retreat as an independent, comparatively new reason for termination of the obligation in the civil law of Ukraine in order to improve the practice of applying national legislation in this area and a general understanding of the nature of retreat and relevant legal relations.

Key words: retreat, legal relations, cessation of the obligation, replacement of the subject of the obligation, redemption agreement, legal features. 